only a much needed re-evaluation of Irigaray's work, but an interrogation of the question of the place of women in philosophy which deserves wide reading and discussion.

\section{Jean Grimshaw}

\section{The Rites of Man: Love, Sex and Death in the Making of the Male}

Rosalind Miles

Grafton: London 1991

ISBN 024613474 7, £14.99 Hbk

ISBN $058609220 x, £ 6.99 \mathrm{Pbk}$

The Rites of Man opens with a prologue containing gruesome tales of male violence in which Miles expresses the urgency to discover its cause. This, she claims, lies in the social construct of masculinity. The rest of the book, then, examines the ways in which men acquire masculinity, and the effects it has on them, on other men, and (to a lesser extent) on women. The central thesis is that murderers and rapists are not psychopaths, but just ordinary men whose violence is the result of the pressures inherent in socially acquired masculinity. Violence is, in one way or another, essential to being a 'real man', and will not disappear until an end is brought to the 'rites of man', which instil masculinity in males. Just a few of the institutions held responsible for the reproduction of these rites are the family, public schools, gangs, sport and war. These are examined in the course of the argument, which is divided (somewhat unclearly) into sections on childhood, growing up, manhood and old age.

However, already in the first two chapters, it is mothers and mother-substitutes who receive the blame for men's behaviour, particularly, it seems, those who are loving and caring. Once again the problem of men becomes the fault of women: 'Quite unavoidably then [my emphasis], adult male heterosexuality will contain strong elements of terror and anger, fantasies of rôle reversal and revenge against women, a blanket urge to punish someone, anyone, for what mother has done.' (p. 30)

In fact, this appears to be a book on masculinity which pays very little attention not only to feminism, but to women. It is a valid point that men, too, suffer from the ever more demanding masculine ideal, which today insists that a man not only 'succeed', and 'be a man' but a new man. However, Miles's desire to see an end to violence seems to be based on a wish to save men from the constraints and hardships (physical and mental) of the 'rites of man': if they did not have to participate in these rituals, they would not have to be hurt/killed/upset and the world would be a happier place. 'Because the majority of young men make a safe, successful transition to adulthood, are we to care nothing for those who do not?', she writes (p. 117).

Relying heavily on anecdotal evidence (from actors, politicians, novelists, Cosmopolitan...), this study lacks a strong theoretical framework. The analysis also suffers from the occasional descent into tabloid sensationalism as well as emotionally charged inaccuracies such as this: 'And why has no government, no figure of authority, no campaigner, no parent, ever tried to stop the senseless slaughter on the roads?' (p. 115)

Despite a critique of nuclear families, marriage, the ideology of 'new fathers', Miles fails to go far beyond the exposure of masculine rituals and the institutions which support them - something which was already done in the late 1980 s. This seems to be mainly because she ignores the feminist critique of masculinity which has burgeoned in the past few years. When Miles 
mentions feminism, it is to name it as a cause of the increased pressure on men to assert their masculinity (in response to more independent women), not to analyze the vast amounts of work that feminists have recently produced on this subject.

Race and class are dismissed as valid subjects for analysis on the question of masculinity and male violence on the grounds that some wives of white, middle-class men are also battered. Perhaps, as Miles claims, "neither race nor deprivation holds the key' (p. 220) to male violence, but they are central issues which cannot simply be ignored, not least because the different masculinities which exist in society are then condensed into one. Gay men are also incorporated into the model: 'Homosexual men are and remain men first, last and foremost and as such, like all men [. . . ], they pursue dominance and seek transcendence through the penis.' (p. 152). The struggles by many gay men to challenge the structures of gender and subvert traditional masculinity are not mentioned.

Despite the pessimism she inadvertently evokes through the repetition of words such as 'inevitable', 'inescapable' and 'inexplicable',
Miles does offer some suggestions for future change in her 'twenty-firstcentury blueprint for boys' survival', which includes close, involved fathering; positive rôle-modelling; eliminating violence from school life; and offering positive images of women. As for the violent few, Miles suggests various legal reforms and more research into the causes of male violence. However, she makes no mention of the social, economic and cultural variations in the lives of different men, and the effects which these have on their propensity to violence. Neither does she suggest that improving the socio-economic conditions of many men (and women) would change the power relations which lead to violence.

It would be unfair to be entirely negative about this book. It is written in an engaging style, covers a huge range of subjects and uses detailed descriptions of masculine behaviour from many different cultural and historical contexts. However, for those wanting a more solid, theoretically sound analysis on this subject, it would be better to turn to Lynne Segal's Slow Motion (London: Virago 1990).

\section{Gill Allwood}

WOMEN: their lives and literature. Catalogue of secondhand \& rare books now available from Jane Bell, Fortune Green Bookshop, 74 Fortune Green Rd, London NW6 1DS. 071-435-7545. 